\title{
LAND SLIDING:
}

IMAGINING SPACE, PRESENCE, AND POWER IN CANADIAN WRITING

Why have so many of this century's prominent political and literary critics wanted to find a single metaphor to describe the character of Canada? Why have so many used land-based metaphors in reference to the divisions between centre and margin, colony and empire, wealth and power? W.H. New, in Land Sliding: Imagining Space, Presence, and Power in Canadian Writing, investigates this established paradigm by examining why so many writers have accepted the land as a comprehensive image of nationhood. Is there in fact, he questions, a landscape that is 'natural,' unmediated by social values and literary representation?

Asking what 'land' as an abstract concept and a physical site has to do with writing, representation, and power, New looks at the 'sliding' relationship by which people associate their surroundings with their position in society. New's study of land in literature is a commentary on the way a culture produces values by transforming the 'natural' into literary idiom and, in turn, making literary convention seem natural. Land Sliding develops not as a history of uniformity or progress, but as a series of dialogues between past and present, between paradigms and disciplines. It draws on a wide range of texts, including First Nations narratives, contemporary poetry and fiction, government documents, and real estate ads, as well as artwork and photographs, to illustrate the complex associations that link place, power, and language in Canada today.

W.H. New invites readers to look again at Canada's changing cultural character by rereading both the landscape and the people who have interpreted it. Land Sliding will have an important place in many disciplines, among them literary studies, geography, fine arts, and Canadian studies.

W.H. NEW is a professor of English at the University of British Columbia. He has written more than thirty books, which include literary history and criticism as well as poetry. 
This page intentionally left blank 


\section{W.H. NEW}

\section{Land Sliding:}

Imagining Space,

Presence, and Power

in Canadian Writing

UNIVERSITY OF TORONTO PRESS

Toronto Buffalo London 
www.utppublishing.com

(c) University of Toronto Press Incorporated 1997

Toronto Buffalo London

Printed in Canada

ISBN 0-8020-4119-1 (cloth)

ISBN 0-8020-7962-8 (paper)

(6)

Printed on acid-free paper

\section{Canadian Cataloguing in Publication Data}

New, W. H. (William Herbert), 1938-

Land sliding : imagining space, presence, and power

in Canadian writing

Includes bibliographical references and index.

ISBN 0-8020-4119-1 (bound) ISBN 0-8020-7962-8 (pbk.)

1. Canadian literature (English) - History and criticism.*

2. Land use in literature. 3. Canada in literature.

I. Title.

PS8101.L3N48 $1997 \quad$ C810.9 C96-932283-6

PR9185.5.L3N48 1997

University of Toronto Press acknowledges the assistance to its publishing program of the Canada Council and the Ontario Arts Council.

This book has been published with the help of a grant from the Humanities and Social Sciences Federation of Canada, using funds provided by the Social Sciences and Humanities Research Council of Canada. 
For Peggy, David, and Peter 
This page intentionally left blank 
land.slide (land'slid) $n$. 1. A reconfiguring of land formations, particularly of unstable material (rock, soil, and the like), as, e.g., following glaciation. 2. An overwhelming electoral plurality.

Canada: such a cold, cold country ... a wide land that must be shouted across with electrons.

Douglas Coupland, Microserfs 
This page intentionally left blank 